Article

\title{
Exploring the Determinants of Strategic Corporate Social Responsibility: An Empirical Examination
}

\author{
Sui-Hua $\mathrm{Yu}^{1, *(\mathbb{D})}$ and Wan-Chen Liang ${ }^{2}$ \\ 1 Department of Accounting, National Chung Hsing University, Taichung 40227, Taiwan \\ 2 PricewaterhouseCoopers Taiwan, Taipei 11012, Taiwan; foshe25@gmail.com \\ * Correspondence: shyu@nchu.edu.tw
}

Received: 10 February 2020; Accepted: 16 March 2020; Published: 18 March 2020

check for updates

\begin{abstract}
A growing number of studies propose that the performance outcomes of Corporate Social Responsibility (CSR hereafter) are dependent upon how firms implement CSR. If firms are able to strategically implement CSR, their CSR engagement will not only improve stockholders' value, but will also contribute to corporate sustainability. However, research on strategic CSR is still incipient. This study aims to examine the determinants of strategic CSR. Taking firms that have published CSR reports for three consecutive years as research samples, this study finds that product market competition does not significantly affect the level of strategic CSR, while corporate reputation and customer awareness do both have significantly positive impacts on the level of strategic CSR. These results suggest that the motivation of a firm's engagement in strategic CSR is to respond to external stakeholders' implicit claims rather than to respond to the external competitive pressure.
\end{abstract}

Keywords: strategic corporate social responsibility; product market competition; corporate reputation; customer awareness

\section{Introduction}

It has become increasingly accepted that firms should prioritize environmental stewardship and profit maximization equally [1,2]. With the help of various policies, countries worldwide have made CSR (Corporate Social Responsibility) increasingly accessible. However, the empirical evidence about the relationship between CSR and financial performance is inconsistent [3,4]. Most recent studies argue that CSR performance outcomes depend on how firms implement their CSR initiatives [5-7]. If firms are able to strategically implement CSR, their CSR engagement will not only improve stockholders' value, but also contribute to corporate sustainability [8-11]. Strategic CSR is thus recognized as an important trend worthy of being investigated [12-14]. Distinct from charity, strategic CSR emphasizes using CSR activities to support corporate strategy. It is believed that firms can maximize profits while satisfying social needs by linking CSR to their core business activities and cultivating close relationships with stakeholders [15-17].

Despite the fact that the focus of CSR research has shifted from diverse CSR activities to the strategic role of CSR over the past two decades, research on strategic CSR is still in an early stage. Many studies are calling for further attention on this issue, particularly the motivations of a firm's strategic CSR initiatives $[1,10,16,18]$. To fill the research gap, this study empirically examines the determinants of strategic CSR. Specifically, we investigate the impact of product market competition, corporate reputation, and customer awareness on the level of strategic CSR to understand how external competitive pressure and external stakeholder claims motivate a firm to implement strategic CSR.

Stakeholder theory holds that exposure to external stakeholder claims will affect a firm's corporate decisions [19-21]. A stakeholder is defined as "any group or individual who can affect or is affected by the achievement of an organization's objectives" [22]. Stakeholder claims include explicit and implicit 
claims. The former refers to contractual matters, while the latter relates to company promises to stakeholders [23]. Corporate reputation is built by fulfilling promises from implicit claims and signaling that future implicit claims will be honored [23,24]. As a firm's reputation improves, it experiences greater pressure to meet external stakeholders' implicit claims. Customer awareness reflects a firm's corporate visibility. Increasing customer awareness increases a firm's exposure to external stakeholders' implicit claims. By investigating the impact of corporate reputation and customer awareness on the level of strategic CSR, we can understand how external stakeholders' implicit claims motivate a firm to engage in strategic CSR.

Using publicly-listed companies that issued CSR reports for three consecutive years as research sample, this study finds that product market competition does not significantly affect the implementation of strategic CSR, while corporate reputation and customer awareness positively impact the implementation of strategic CSR. This study provides important findings and contributes to scholarly literature in several ways. First, it shows that the motivation of a firm's engagement in strategic CSR is to respond to external stakeholders' claims rather than responding to external competitive pressure. Although some recent studies have touched on the issue of motivations for CSR [25-28], they do not compare the impact of external competitive pressure or stakeholder claims. Second, we address the importance of corporate reputation in driving a firm's strategic CSR initiatives. Most studies focus on examining how CSR initiatives increase reputational capital [29-31]. However, this study indicates that corporate reputation could affect a firm's strategic CSR initiatives. Having successfully fulfilled stakeholder implicit claims in the past, a firm faces greater pressure to meet stakeholder expectations in the future. Thus, a well-regarded firm will be more willing to engage in strategic CSR to sustain its reputation. Third, we discuss the role of customer awareness in driving a firm's strategic CSR initiatives. External stakeholders can be classified into primary stakeholders, such as customers, and secondary stakeholders, such as the public [21,32]. Existing studies mostly analyze corporate visibility from the public's perspective, identifying it as a key factor in affecting a firm's CSR initiatives $[26,33,34]$. This study analyzes corporate visibility from the customers' perspective. Improving a firm's visibility to customers increases its exposure to stakeholders' implicit claims, adding importance to a firm's strategic CSR initiatives.

\section{Literature Review and Hypotheses Development}

\subsection{Definitions and Characteristics of Strategic CSR}

According to the definition given by McWilliams and Siegel [17], strategic CSR enables firms to gain a long-term competitive advantage for either moral purposes, i.e., preventing or compensating for damage done to society, or charitable purposes, i.e., actively giving back to society and meeting social expectations. Specifically, CSR can be classified into three types by purpose and nature: Moral CSR, altruistic CSR, and strategic CSR [35]. Moral CSR is carried out in light of moral norms, whereas altruistic CSR or, "humanistic CSR," is carried out just because firms want to become good citizens and benefit society irrespective of their financial returns [35]. By contrast, strategic CSR is carried out because firms want to develop a sustainable competitive advantage [17]. Vishwanathan et al. [2] further define strategic CSR as those firm activities that can generate social good and simultaneously create financial outcomes.

Through a comprehensive review of CSR research, we summarize the characteristics of strategic CSR as follows. First, while engaging in strategic CSR, firms think highly of stakeholders [1,36-38]. Specifically, firms' operating activities will affect the benefits of stakeholders, and the needs of stakeholders will affect the firms' operational objectives. It is crucial to consider the benefits of stakeholders while improving the operational performance of firms. When carrying out their strategic CSR, firms tend to think from a strategic perspective, identifying the social responsibility activities that benefit stakeholders $[36,39]$ while also satisfying their unique needs [40]. Therefore, the undertaking of strategic CSR must be an interactive process that evokes positive responses from different stakeholders [1]. 
Second, strategic CSR emphasizes the coexistence of commercial and social benefits [2,41,42]. Porter and Kramer [43] promote the concept of "strategic charity," arguing that social and economic objectives can be linked in the long term. Many economic investments involve social returns, while many social investments produce economic benefits. When deciding whether to carry out a CSR initiative, firms should conduct a benefit analysis beforehand. The intent of strategic CSR is to ensure that the implemented activities can benefit both society and the firms, thus improving overall social and economic value and producing a win-win outcome $[41,43,44]$. CSR can be used to help firms accomplish their strategic objectives—known as the "strategization of CSR" —and social objectives will boost the firms' economic benefits in the long term even if they may bring about the loss of some economic benefits in the short term [35].

Third, strategic CSR is closely integrated into corporate core business activities [45-48]. Brammer and Pavelin [45] believe that it is of strategic significance to identify the scope and content of CSR activities accurately, with each firm developing an initiative suited to its scale and competencies. Porter and Kramer [41] propose the concept of "creating shared value," arguing that CSR combined with corporate core competencies lays the foundation for maintaining a competitive advantage. Gelbmann [36] characterizes strategic CSR as combining CSR with core business processes. Specifically, CSR with a strategic consideration will not only contribute to the internal value chain activities of firms, but will also boost their external competitiveness. Székely and Knirsch [49] also contend that the strategization of CSR can help firms establish their external competitiveness or directly invest in internal operational activities. Several studies argue that strategic CSR should integrate responsible actions into core business processes and embed efforts in daily businesses $[48,50,51]$.

\subsection{Impact of Product Market Competition on Strategic CSR}

External competitive pressure is considered an important motive for a firm to undertake strategic CSR [52]. Facing a higher level of product market competition, a firm bears a greater level of external competitive pressure [53]. A product market can be regarded as a dynamic exchange system comprising sellers, products, and customers. The simplest form of a product market is that in which a single seller provides a single product for a single customer [54]. A high degree of competition in a product market will reinforce the firm's strategic consideration in the implementation of CSR [55]. Several studies also find that the pressure of competition forces firms to think highly of stakeholders and improve their CSR performance related to consumers and employees [1,42,53].

Moreover, as competition increases, firms tend to improve their performance with respect to product quality and safety [56]. This shows that a high degree of competition in the product market will encourage a firm's engagement in strategic CSR. Besides, in the face of competitive pressure, firms tend to strategically adopt CSR policies to offer a market premium [18]; increase their investment in CSR to differentiate themselves from their competitors; and build deep relationships with stakeholders through strategic CSR to acquire comparative advantages [53]. It is generally believed that CSR can be used as a product differentiation strategy to gain a preemptive advantage for high-quality products [57]. Strategic CSR also can help firms operate their business more efficiently and attain an environment-cost balance in a highly-competitive market [58]. Given that strategic CSR is an effective way to cope with market competition, we expect that increasing product market competition will increase a firm's motivation to implement strategic CSR. Therefore, this study presents the first hypothesis as follows:

Hypothesis 1. Product market competition will positively impact the level of strategic CSR.

\subsection{Impact of Corporate Reputation on Strategic CSR}

Corporate reputation represents the overall evaluation given by stakeholders [59], and reflects a collective impression about a firm over time [60,61]. It encompasses a number of different dimensions and is associated with a firm's resources and competencies. Corporate reputation is built by fulfilling promises associated with stakeholders' implicit claims [23]. In other words, corporate reputation 
reflects a firm's success in consistently meeting stakeholders' expectations. A firm with a stronger reputation thus shoulders greater pressure to fulfill stakeholders' implicit claims. Without meeting stakeholders' expectations, a firm will lose the reputational capital that it has accumulated over time [62]. Given that strategic CSR is an important channel through which to satisfy the requirements of various stakeholders [2], a firm with robust corporate reputation will be motivated to engage strategic CSR to maintain or improve its corporate reputation.

In addition, it is more likely for a firm with a sound reputation to generate social and commercial benefits through CSR initiatives. It is believed that a strong corporate reputation not only improves a firm's external perceptions among stakeholders, but also benefits its internal business activities. Specifically, corporate reputation has the potential to create value because it is difficult for competitors to imitate [63]. Further, corporate reputation is regarded as a hidden signal of product and service quality. Customers thus are more willing to pay a premium to buy products or services provided by firms with a good reputation. What's more, employees identify more with firms that have a good reputation and are thus more willing to work harder and stay longer, which can boost the cost advantage for firms [42]. To keep up with the advantages described above, firms with a strong corporate reputation will engage in strategic CSR to sustain their corporate reputation.

Moreover, firms with a strong corporate reputation will be more likely to integrate CSR activities into their core business. Previous studies contend that corporate reputation is beneficial for managing operational risks. Specifically, a firm's corporate reputation can solve agency problems arising from undercapitalization due to the inefficient use of free cash flows [64]. A stronger corporate reputation also enables firms to develop closer relationships with their stakeholders so that the stakeholders are more willing to share information with them [65]. Corporate reputation can help firms pull through crises, prevent corporate value from being impaired by destabilizing events, and even help firms recover from such incidents faster than others $[48,66]$. Benefits such as risk mitigation and more fluid information sharing gives firms with strong corporate reputations a stronger motive to engage in strategic CSR.

In summary, a strong reputation exposes firms to added pressure to fulfill stakeholder expectations. Strategic CSR is believed to be an effective tool in responding to stakeholders' implicit claims [67]. A firm with a strong reputation thus will be more motivated to engage in strategic CSR to sustain its reputation and maintain its established advantages. Hence, this study develops the second hypothesis as follows:

Hypothesis 2. Corporate reputation will positively impact the level of strategic CSR.

\subsection{Impact of Customer Awareness on Strategic CSR}

Customer awareness refers to customers' awareness about the firm [68], which reflects the extent to which a firm is visible to its customers. Enhancing customer awareness will expose a firm to its external stakeholders' implicit claims. Failure to comply could disappoint stakeholders and lead to negative opinions of the firm [26]. Therefore, a firm with elevated customer awareness will think more highly of stakeholders and will be more willing to engage in strategic CSR. As a firm's customer awareness increases, the exposure to stakeholder implicit claims increases, and its strategic CSR initiatives will become increasingly necessary.

In addition, increasing customer awareness not only improves a firm's corporate visibility to customers, but also prompts customers to become better informed about the firm's CSR activities [68]. Elevated customer awareness increases the visibility of a firm's CSR initiatives, which increases the probability of a firm's success in its CSR initiatives $[69,70]$. Studies show that customers who are aware of a firm's CSR initiatives will develop a higher-quality perception of that firm's products [71], be more likely to purchase the firm's products or services [1,72], and will also be more willing to pay higher prices for the firm's products or services [73,74]. In other words, a firm with higher customer awareness will be more likely to obtain social goodwill and financial benefits simultaneously. As a firm's CSR 
initiatives are more visible to its customers, firms are more likely to benefit from its CSR practices. Therefore, customer awareness is an important factor that drives a firm to engage in strategic CSR.

In summary, increasing customer awareness will increase a firm's corporate visibility and thus increase a firm's exposure to external stakeholders' implicit claims. To avoid negative public opinion, a firm will engage in strategic CSR to fulfill external stakeholder claims. What's more, greater visibility also provides a firm with more opportunities to benefit from its strategic CSR initiatives. Therefore, this study expects that customer awareness will positively impact the level of strategic CSR and presents the third hypothesis as follows:

Hypothesis 3. Customer awareness will positively impact the level of strategic CSR.

\section{Research Methodology}

\subsection{Sample and Data}

We test our hypotheses using data collected from publicly-listed firms in Taiwan. The sample period covers 2012 to 2014. Most of the measurement data on the level of strategic CSR came from CSR reports and annual reports published by sample firms on their official websites. Data on transparency in corporate governance were collected from the evaluation scores of information disclosure released by the Corporate Governance Center of the Taiwan Stock Exchange. Data for the independent variables, control variables, and financial performance, as well as industry categories were collected from the Taiwan Economic Journal (TEJ) databases. Specifically, data used to calculate measures for product market competition, corporate reputation, customer awareness, financial performance, and control variables were collected from the Financial Database in TEJ, whereas data on industry categories were obtained from the Firm Attribute Database in the TEJ.

\subsection{Variable Measurement}

\subsubsection{Level of Strategic CSR (STCSR)}

We calculate level of strategic CSR following two stages. In the first stage, CSR performance is divided into six dimensions, including corporate governance, diversity, employee relations, community, environment, and product. Each dimension involves three indicators, and each indicator is evaluated according to the specified qualitative or quantitative criteria listed in Table 1. An indicator is given a score of 1 if it meets the specified criteria, and a score of 0 if it does not. Then, the scores of all the dimensions are summed to obtain the original CSR score. The maximum original CSR score is 18 , indicating that a firm has the highest CSR performance, while the minimum original CSR score is 0 , indicating that a firm has the lowest CSR performance.

In the second stage, we refer to Tang, Hull, and Rothenberg [75], and transform CSR performance into the level of strategic CSR in terms of three aspects, including pace, relatedness, and consistency. Pace (PACSTCSR) indicates the speed at which a firm integrates CSR into its business operation; it can reflect whether CSR is integrated into the enterprise's core business perfectly. A slower speed of integration usually indicates a more perfect integration [76]. Relatedness (RESTCSR) is mainly used to measure the degree of relatedness among different aspects of CSR. Based on the path dependency theory, the similarity and heterogeneity of input activities determine whether a firm can develop auxiliary resources to attain a harmonious cooperation among different aspects [77,78]. Higher relatedness thus indicates that a firm is able to attain a more harmonious cooperation, and is more likely to achieve success in both of social performance and financial performance. Consistency (CONSTCSR) reflects the extent to which a firm carries out CSR systematically and regularly [79]. Based on the path dependency theory, consistency in the implementation of CSR will help firms accumulate and absorb CSR knowledge, develop complementary resources in a regular manner, gain an in-depth understanding of stakeholders' benefits, and thus building a trusting relationship with stakeholders [80]. Higher consistency thus indicates a firm think more highly of the benefits of stakeholders. 
We describe the calculation methods for pace, relatedness, and consistency, respectively. First, we subtract the average original CSR scores of the previous two years to the current year from the original CSR scores of the current year, and divide these differences by the original CSR scores for the current year. Subsequently, we group these values by quartiles in descending order, and given the groups a score of 1 to 4 . Specifically, the group with the lowest differences is given a score of 4 , and the group with the highest differences is given a score of 1 . A higher score represents a lower speed of incorporating CSR into a firm, which indicates a higher degree of pace (PACSTCSR).

Table 1. Components of Original Corporate Social Responsibility (CSR) Scores.

\begin{tabular}{|c|c|c|c|}
\hline Dimension & Group & Indicator & Standard \\
\hline \multirow{3}{*}{$\begin{array}{l}\text { Corporate } \\
\text { Governance }\end{array}$} & \multirow{3}{*}{ Internal } & Transparency & $\begin{array}{l}\text { The score of the information disclosure indicator is } 60 \text { points or } \\
\text { more (A- or above). }\end{array}$ \\
\hline & & No negative events & No reports of negative events are recorded in the TEJ. \\
\hline & & CSR Award & $\begin{array}{l}\text { The firm is given the Excellence in Corporate Social Responsibility } \\
\text { Award in the current year. }\end{array}$ \\
\hline \multirow{3}{*}{ Diversity } & \multirow{3}{*}{ Internal } & Equal rights organization & $\begin{array}{l}\text { Female employees and employees from disadvantaged groups } \\
\text { jointly account for at least } 40 \% \text {. }\end{array}$ \\
\hline & & $\begin{array}{l}\text { Policy for disadvantaged } \\
\text { groups }\end{array}$ & $\begin{array}{l}\text { The firm innovates in or improves the employment of people } \\
\text { with disabilities. }\end{array}$ \\
\hline & & $\begin{array}{l}\text { Diversity of corporate } \\
\text { culture }\end{array}$ & $\begin{array}{l}\text { The firm builds a tolerant organizational culture, where the } \\
\text { employees come from different backgrounds, lifestyles, cultures, } \\
\text { and areas of expertise, and all the employees work effectively } \\
\text { and cooperatively. }\end{array}$ \\
\hline \multirow{3}{*}{$\begin{array}{l}\text { Employee } \\
\text { Relations }\end{array}$} & \multirow{3}{*}{ Internal } & Labor union & A labor union is founded in the firm. \\
\hline & & Health and safety & $\begin{array}{l}\text { The firm arranges health examinations for employees regularly and } \\
\text { carries out measures and activities to care for the physical and } \\
\text { psychological health of its employees. }\end{array}$ \\
\hline & & Employee training & $\begin{array}{l}\text { The firm develops a complete employee training program, a clear } \\
\text { promotion system, and a regular continuing education program. }\end{array}$ \\
\hline \multirow{3}{*}{ Community } & \multirow{3}{*}{ External } & Financial donations & $\begin{array}{l}\text { The firm made donations to aid disadvantaged groups, people } \\
\text { stricken by major disasters, or charity organizations. }\end{array}$ \\
\hline & & Non-financial donations & $\begin{array}{l}\text { The firm provided material, service, or technology donations to aid } \\
\text { disadvantaged groups, people affected by major disasters, or } \\
\text { charity organizations. }\end{array}$ \\
\hline & & $\begin{array}{l}\text { Community } \\
\text { identification }\end{array}$ & $\begin{array}{l}\text { The firm establishes a good relationship with local residents } \\
\text { and gets on well with local residents in terms of human rights } \\
\text { and culture. }\end{array}$ \\
\hline \multirow{3}{*}{ Environment } & \multirow{3}{*}{ External } & $\begin{array}{l}\text { Pollution control } \\
\text { program }\end{array}$ & $\begin{array}{l}\text { The firm sets up sewage and waste treatment facilities and takes } \\
\text { measures to reduce carbon emissions, water footprints, or the } \\
\text { generation of toxic substances. }\end{array}$ \\
\hline & & Management system & $\begin{array}{l}\text { The firm's internal management system meets international } \\
\text { certification standards. }\end{array}$ \\
\hline & & Recycling & $\begin{array}{l}\text { The firm uses renewable resources, provides eco-friendly products } \\
\text { or services, uses recycled materials as production materials, or has } \\
\text { signed onto the principles of environmental protection. }\end{array}$ \\
\hline \multirow{3}{*}{ Product } & \multirow{3}{*}{ External } & Quality management & $\begin{array}{l}\text { The manufacturing settings of machinery and equipment focus on } \\
\text { the maintenance and management of environmental quality and the } \\
\text { establishment of quality assurance or health and safety systems. }\end{array}$ \\
\hline & & Customer satisfaction & $\begin{array}{l}\text { The firm builds a complete mechanism for customer } \\
\text { communication, responds to customer needs in real time, } \\
\text { and measures customer satisfaction. }\end{array}$ \\
\hline & & $\begin{array}{l}\text { Supply chain } \\
\text { management }\end{array}$ & $\begin{array}{l}\text { The firm builds a mechanism for regular supplier evaluation, jointly } \\
\text { develops technologies with suppliers, and establishes criteria for } \\
\text { supplier selection. }\end{array}$ \\
\hline
\end{tabular}


Second, we calculate the Pearson correlation coefficients of each CSR dimension with the other five CSR dimensions and then sum up the five correlation coefficients to obtain the relatedness of each single dimension. Then, we sum up the six CSR dimensions' relatedness measures to obtain a firm-level relatedness measure. Subsequently, all firm-level relatedness measures are grouped by quartiles in ascending order, and the groups are given a score of 1 to 4 . Specifically, the group with the highest firm-level relatedness measures is given a score of 4 , and the group with the lowest firm-level relatedness measures is given a score of 1 . The higher the score of a quartile group, the higher the degree of relatedness (RESTCSR).

Third, we calculate the standard deviation of the original CSR scores for the previous two years to the current year for each firm. Subsequently, the standard deviations are grouped by quartiles in descending order, and the groups are given a score of 1 to 4 . Specifically, the group with the lowest standard deviations is given a score of 4 , and the group with the highest standard deviations is given a score of 1 . The higher the score of a quartile group, the higher the consistency in the implementation of CSR, which indicates a higher level of consistency (CONSTCSR).

Finally, we take the sum of the scores for pace (PACSTCSR), relatedness (RESTCSR), and consistency (CONSTCSR) to obtain the measure for the level of strategic CSR (STCSR), which is in the range of 3 to 12 .

\subsubsection{Product Market Competition (COMP)}

This study uses the Herfindahl-Hirschman Index (HHI) to measure the level of product market competition, which is the measurement method proposed by Fernández-Kranz and Santaló [55]. The HHI value is equal to the sum of the squares of the ratio of the sales revenue of each firm to the total sales revenues of all firms in one industry. The calculation formula is as follows:

$$
H H I_{t}=\sum_{i=1}^{n} \alpha_{i, t}^{2}
$$

where $\alpha_{i, t}=\frac{q_{i, t}}{Q_{t}} ; Q_{t}=\sum_{i=1}^{n} q_{i t}, i=1 \ldots n$ indicates the $i$-th firm in an industry, $t$ indicates the year, $q_{i t}$ indicates the sales revenue of the $i$-th firm in the $t$-th year, and $Q_{t}$ indicates the sum of sales revenue of all firms in the industry in the $t$-th year. According to the industry categories defined in TEJ, this study calculates the HHI value for each industry in each year. The lower the HHI value, the higher the level of product market competition.

\subsubsection{Corporate Reputation (REPU)}

Given that many studies use market share to measure corporate reputation [81-83], this study also uses market share to measure corporate reputation. To reduce the correlation between the measure of corporate reputation and the measure of product market competition, we subtracted the median of the market share of the industry from each firm's market share to obtain the measure of corporate reputation as follows.

Market share $=[($ sales revenue of a firm $) /($ total sales revenue of all firms in one industry $)]-$ (Median of market share of the industry).

\subsubsection{Customer Awareness (ADVE)}

Following prior studies $[57,60,68]$, this study uses advertising intensity to measure customer awareness. When a firm increases its advertisement and media exposure, customers will become aware of its CSR initiatives more easily. Therefore, this study calculates advertising intensity as follows to measure customer awareness:

Advertising intensity $=($ Advertising expenses $) /($ Total operating expenses $)$. 


\subsubsection{Control Variables}

Management Capability (TURN): The management capability of firms may affect the effectiveness of CSR implementation. Therefore, this study includes management capability as a control variable and measures management capability in terms of asset turnover: We divided sales revenue by total assets at the end of each year to obtain asset turnover.

Financial Leverage (LEVER): An extremely high debt ratio may affect a firm's implementation of CSR [84]. Therefore, this study uses financial leverage as a control variable, which is measured in terms of debt ratio.

Size of Board of Directors (DS): A large board of directors will help firms to obtain more resources in CSR activities and gain an in-depth understanding of stakeholder demands. Therefore, the size of the board of directors may affect firms' decisions about whether to engage strategic CSR. Therefore, this study includes the size of board of directors as a control variable, which is measured in terms of the number of directors and supervisors.

Holding Percentage of Large Shareholders (MS): Equity dispersion implies diverse share holdings. This may affect a firm's decisions to invest in CSR activities [85]. When the equity structure tends to be dispersed, diverse shareholders will show more concern for the implementation of CSR. Therefore, it is necessary to control for the effect of ownership structure on the level of strategic CSR.

Shareholding Percentage of External Legal Persons (EXCO): External legal persons can not only supervise the implementation of corporate policies in a timely manner, but also provide rich resources to firms in a timely manner, thus facilitating the implementation of strategic CSR. This study thus includes this control variable.

Shareholding Percentage of Government Institutions (INST): Unlike firms, governments are sometimes duty-bound to care for society. Firms with higher shareholding percentage of government institutions may increase their investment in CSR activities. This study thus includes this control variable.

Year Dummies (YEAR): This study examines sample companies from three consecutive years. Thus, this study includes two-year dummies to control for the time effect.

\subsection{Empirical Models}

To examine the determinants of strategic CSR, this study builds the empirical model as follows to test Hypotheses 1, 2, and 3. This study uses the level of strategic CSR at year $t+1$ as dependent variable to cast aside the concern about the potential endogeneity issue arising from the impact of CSR on corporate reputation. If the coefficient on the product market competition is significantly negative (i.e., $\beta_{2}<0$ ), it supports the prediction of the first hypothesis. That is, higher market competition will lead to higher level of strategic CSR. If the coefficient on the corporate reputation is significantly positive $\left(\beta_{3}>0\right)$, it supports the prediction of the second hypothesis. That is, higher corporate reputation will lead to higher level of strategic CSR. If the coefficient on the customer awareness is significantly positive $\left(\beta_{4}>0\right)$, it supports the prediction of the third hypothesis. That is, higher customer awareness will lead to higher level of strategic CSR.

$$
\begin{aligned}
\operatorname{STCSR}_{i, t+1}= & \beta_{1}+\beta_{2} \operatorname{COMP}_{i, t}+\beta_{3} \operatorname{REPU}_{i, t}+\beta_{4} A D V E_{i, t} \\
& +\beta_{5} \operatorname{TURN}_{i, t}+\beta_{6} \mathrm{LEVER}_{i, t}+\beta_{7} D S_{i, t}+\beta_{8} M S_{i, t} \\
& +\beta_{9} E \mathrm{XCO}_{i, t}+\beta_{10} I_{N S T_{i, t}}+\sum_{j=1}^{2} \delta_{j} Y E A R_{i, j, t} \\
& +\varepsilon_{i, t}
\end{aligned}
$$

where,

$\operatorname{STCSR}_{i, t+1}$ : Level of strategic CSR for firm $i$ at year $t+1$.

$\operatorname{COMP}_{i, t}$ : Level of product market competition measured by the HHI index for firm $i$ at year $t$.

$R E P U_{i, t}$ : Level of corporate reputation measured by the market share for firm $i$ at year $t$.

$A D V E_{i, t}$ : Level of customer awareness measured by the advertising intensity for firm $i$ at year $t$.

$\operatorname{TURN}_{i, t}$ : Level of management capability measured by the asset turnover ratio for firm $i$ at year $t$. 
$L E V E R_{i, t}:$ Level of financial leverage measured by the debt ratio for firm $i$ at year $t$.

$D S_{i, t}$ : Size of board of directors for firm $i$ at year $t$.

$M S_{i, t}$ : Holding percentage of large shareholders for firm $i$ at year $t$.

$E X C O_{i, t}$ : Shareholding percentage of external legal persons for firm $i$ at year $t$.

$I N S T_{i, t}$ : Shareholding percentage of government institutions for firm $i$ at year $t$.

$Y E A R_{i, j, t}$ : Year dummies for firm $i$ at year $t$.

\section{Empirical Results}

We list the descriptive statistics of all variables in Table 2. As seen from Table 2, the lowest value of strategic CSR (STCSR) is 3, the highest is 11, and the average is 7.89. This shows there is a great difference in the level of strategic CSR between companies. The lowest product market competition $(C O M P)$ is 0.0569 , the highest is 0.8507 , and the average is 0.3064 . This shows that there is a wide range in the level of product market competition that sample companies face. As for corporate reputation $(R E P U)$, the minimum value is -0.1465 , the maximum value is 0.7625 , and the average is 0.1886 . This shows that firms with high corporate reputation and firms with low corporate reputation are all included in the research sample so that we can examine how corporate reputation affects firms' engagement in strategic CSR. Regarding customer awareness, the average is 0.0213 , indicating that sample companies have lower advertising intensity. Besides, we find that there is a great variation in the value of each control variable between sample companies, indicating that these variables are required to be controlled.

Table 2. Descriptive Statistics.

\begin{tabular}{cccccc}
\hline Variables & $\mathbf{N}$ & Mean & Std. Dev & Min & Max \\
\hline STCSR & 196 & 7.8900 & 1.6101 & 3 & 11 \\
COMP & 196 & 0.3064 & 0.1633 & 0.0569 & 0.8507 \\
REPU & 196 & 0.1886 & 0.1983 & -0.1465 & 0.7625 \\
ADVE & 196 & 0.0213 & 0.0504 & 0 & 0.3286 \\
TURN & 196 & 0.9200 & 0.6694 & 0.0101 & 3.0085 \\
LEVER & 196 & 1.0419 & 0.4757 & -1.29 & 3.93 \\
DS & 196 & 10.9235 & 3.1735 & 6 & 25 \\
MS & 196 & 19.4766 & 10.1957 & 3.28 & 65.88 \\
EXCO & 196 & 14.0554 & 9.1292 & 0 & 40.92 \\
INST & 196 & 2.8971 & 7.0524 & 0 & 39.16 \\
\hline
\end{tabular}

As seen from the correlation analysis of Table 3 below, there is a positive correlation between corporate reputation (REPU) and the level of strategic CSR (STCSR). In other words, firms with higher corporate reputation are more willing to engage in strategic CSR, which is the expected outcome. As for the correlation between product market competition (COMP) and strategic CSR (STCSR), it is insignificant. So does the correlation between customer awareness (ADVE) and strategic CSR (STCSR). We further examine these two relationships using regression analyses as follows.

The results of the regression analyses in regards to the determinants of strategic CSR are shown in Table 4. As seen from Table 4, the coefficient for corporate reputation (REPU) is positive and significant (coefficient $=1.386$, $\mathrm{t}$ value $=2.102)$ and the coefficient for customer awareness $(A D V E)$ is positive and significant (coefficient $=4.443, \mathrm{t}$ value $=1.874$ ). In other words, the relationships between corporate reputation and strategic CSR and the relationship between customer awareness and strategic CSR are both significantly positive, which support the second and the third hypotheses, respectively. However, the coefficient for product market competition $(C O M P)$ is negative and insignificant (coefficient $=-0.020$, $\mathrm{t}$ value $=-0.025)$, which does not support the prediction of the first hypothesis. The above results indicate that corporate reputation and customer awareness will increase a firm's investment in strategic CSR, and thus increase the level of strategic CSR. Regarding the control variables, this study finds that the coefficient on the size of board of directors $(D S)$ is significantly positive (coefficient $=0.085$, 
$\mathrm{t}$ value $=2.280$ ), indicating that large board size increases a firm's strategic CSR initiatives. This study also finds that the coefficient on the shareholding percentage of government institutions (INST) is significantly negative (coefficient $=-0.042$, $\mathrm{t}$ value $=-2.344$ ), indicating that a firm's ownership structure could affect its CSR initiatives. Consistent with previous studies $[27,86,87]$, we find that a firm's corporate governance mechanisms could affect its CSR decisions. Therefore, it is valid for this study to include theses variables as control.

Table 3. Correlation Analyses.

\begin{tabular}{ccccccccccc}
\hline Variables & STCSR & COMP & REPU & ADVE & DS & MS & EXCO & INST & TURN & LEVER \\
\hline STCSR & & 0.119 & $0.187^{* *}$ & 0.065 & 0.139 & 0.020 & 0.084 & -0.074 & 0.040 & 0.020 \\
COMP & 0.111 & & $0.333^{* *}$ & -0.029 & 0.030 & 0.017 & 0.108 & 0.016 & 0.075 & -0.113 \\
REPU & $0.174^{*}$ & $0.450^{* * *}$ & & -0.056 & $0.142^{*}$ & 0.078 & $0.178^{*}$ & $0.186^{* *}$ & -0.063 & 0.071 \\
ADVE & 0.076 & 0.102 & 0.040 & & -0.082 & 0.135 & 0.083 & 0.081 & -0.058 & $0.165^{*}$ \\
DS & $0.155^{*}$ & 0.055 & 0.073 & -0.021 & & -0.056 & $0.206^{* *}$ & $0.157^{*}$ & $-0.251^{* *}$ & 0.036 \\
MS & -0.017 & 0.072 & $0.169^{*}$ & 0.003 & -0.071 & & $0.417^{* *}$ & $0.185^{* *}$ & -0.083 & $0.155^{*}$ \\
EXCO & 0.090 & $0.186^{* *}$ & $0.172^{*}$ & -0.002 & $0.150^{*}$ & $0.395^{* * *}$ & & $0.264^{* *}$ & -0.079 & 0.077 \\
INST & -0.075 & 0.047 & 0.132 & $0.277^{* * *}$ & $0.204^{* *}$ & -0.010 & $0.226^{* *}$ & & $-0.312^{* *}$ & $0.147^{*}$ \\
TURN & 0.016 & 0.069 & -0.116 & -0.036 & $-0.165^{*}$ & -0.059 & -0.075 & $-0.204^{* *}$ & & -0.069 \\
LEVER & -0.091 & -0.034 & -0.118 & 0.094 & -0.004 & 0.031 & 0.086 & 0.0842 & 0.0334 & \\
\hline
\end{tabular}

Note 1: Pearson coefficients appear in the lower triangle; Spearman coefficients appear in the upper triangle. Note 2: *** indicate $1 \%$ significant level; ${ }^{* *}$ indicate $5 \%$ significant level; ${ }^{*}$ indicate $10 \%$ significant level.

Table 4. The Determinants of Strategic CSR.

\begin{tabular}{|c|c|c|c|c|c|}
\hline Variables & Expected Sign & Regression Coefficients & t Value & P Value & VIF \\
\hline Constant & $?$ & $6.625^{* * *}$ & 10.266 & 0.000 & - \\
\hline COMP & - & -0.020 & -0.025 & 0.980 & 1.324 \\
\hline REPU & + & $1.386^{* *}$ & 2.102 & 0.037 & 1.356 \\
\hline$A D V E$ & + & $4.443^{*}$ & 1.874 & 0.063 & 1.131 \\
\hline TURN & $?$ & 0.115 & 0.648 & 0.518 & 1.112 \\
\hline LEVER & ? & -0.246 & -1.020 & 0.309 & 1.045 \\
\hline DS & $?$ & $0.085^{* *}$ & 2.280 & 0.024 & 1.102 \\
\hline MS & $?$ & -0.013 & -1.066 & 0.288 & 1.255 \\
\hline EXCO & $?$ & 0.021 & 1.496 & 0.136 & 1.349 \\
\hline INST & ? & $-0.042^{* *}$ & -2.344 & 0.020 & 1.258 \\
\hline YEAR1 & ? & 0.200 & 0.667 & 0.505 & 1.627 \\
\hline YEAR2 & $?$ & 0.341 & 1.163 & 0.246 & 1.664 \\
\hline \multicolumn{5}{|c|}{ Sample Size } & 196 \\
\hline \multicolumn{5}{|c|}{ F Value } & 1.948 \\
\hline \multicolumn{5}{|c|}{ Prob $>$ F } & 0.036 \\
\hline \multicolumn{5}{|c|}{ R-squared } & 0.104 \\
\hline \multicolumn{5}{|c|}{ Adj R-squared } & 0.051 \\
\hline \multicolumn{5}{|c|}{ Durbin Watson Statistics } & 1.778 \\
\hline
\end{tabular}

Note: ${ }^{* * *}$ indicates $1 \%$ significance level; ${ }^{* *}$ indicate $5 \%$ significance level; ${ }^{*}$ indicates $10 \%$ significance level.

Given that some studies show that corporate governance could affect corporate reputation and CSR simultaneously [88,89], this study implements an additional analysis to deal with this potential endogeneity issue. Based on prior studies, a firm with a larger size of board of directors, higher holding percentage of large shareholders, higher holding percentage of external legal persons, and higher holding percentage of government institutions may have higher corporate reputation [90]. Therefore, we design a corporate governance variable as follows. Firstly, we sort firms based on each of the four variables related to corporate governance (i.e. Size of Board of Directors, Holding Percentage of Large Shareholders, Shareholding Percentage of External Legal Persons, and Shareholding Percentage of Government Institutions) in descending order, respectively. Secondly, we give a score of 1 to those firms with the value of each variable higher than the median, and a score of 0 otherwise. Thirdly, we take the sum of the four scores to obtain an aggregate measure of corporate governance, which is in the range of 0 
to 4 . Finally, we regress corporate reputation on this measure of corporate governance and use the residual (REPU_R) to replace the original corporate reputation variable. From the correlation analyses, we find that the correlations between this new measure of corporate reputation and the four corporate governance related variables are no longer significant, indicating that the potential impact of corporate governance on corporate reputation has been eliminated. We then use this new measure of corporate reputation $\left(R E P U_{-} R\right.$ ) to do regression analyses again and present the results in Table 5 . As shown in Table 5, the coefficient on the new measure of corporate reputation (REPU_R) is significantly positive (coefficient $=1.372, \mathrm{t}$ value $=2.086$ ), which is consistent with our previous analyses.

Table 5. Additional Analyses: Using New Measure of Corporate Reputation.

\begin{tabular}{|c|c|c|c|c|c|}
\hline Variables & Expected Sign & Regression Coefficients & t Value & P Value & VIF \\
\hline Constant & $?$ & $6.802^{* * *}$ & 10.502 & 0.000 & - \\
\hline COMP & - & -0.037 & -0.047 & 0.963 & 1.340 \\
\hline$R E P U \_R$ & + & $1.372^{* *}$ & 2.086 & 0.038 & 1.321 \\
\hline$A D V \bar{E}$ & + & $4.454^{*}$ & 1.878 & 0.062 & 1.131 \\
\hline TURN & $?$ & 0.111 & 0.630 & 0.530 & 1.110 \\
\hline LEVER & $?$ & -0.246 & -1.018 & 0.310 & 1.046 \\
\hline$D S$ & $?$ & $0.089^{* *}$ & 2.385 & 0.018 & 1.103 \\
\hline MS & $?$ & -0.012 & -0.983 & 0.327 & 1.243 \\
\hline EXCO & $?$ & 0.023 & 1.627 & 0.105 & 1.352 \\
\hline INST & $?$ & $-0.041^{* *}$ & -2.294 & 0.023 & 1.252 \\
\hline YEAR1 & $?$ & 0.200 & 0.666 & 0.506 & 1.627 \\
\hline YEAR2 & $?$ & 0.336 & 1.148 & 0.252 & 1.663 \\
\hline \multicolumn{5}{|c|}{ Sample Size } & 196 \\
\hline \multicolumn{5}{|c|}{ F Value } & 1.942 \\
\hline \multicolumn{5}{|c|}{ Prob $>$ F } & 0.037 \\
\hline \multicolumn{5}{|c|}{ R-squared } & 0.104 \\
\hline \multicolumn{5}{|c|}{ Adj R-squared } & 0.050 \\
\hline \multicolumn{5}{|c|}{ Durbin Watson Statistics } & 1.782 \\
\hline
\end{tabular}

Note: ${ }^{* * *}$ indicates $1 \%$ significance level; ${ }^{* *}$ indicate $5 \%$ significance level; ${ }^{*}$ indicates $10 \%$ significance level.

\section{Conclusions and Discussion}

In conclusion, this study has several interesting findings. First, we find that product market competition is not significantly associated with the level of strategic CSR. This indicates that the external competitive pressure is not a driving force of a firm's engagement in strategic CSR. This study further suggests that the motivation of a firm's strategic CSR initiatives is to respond to stakeholders' implicit claims. Different from prior studies examining on determinants of CSR [25-28], this study compares the impact of external competitive pressure and external stakeholder claims. Second, we find that corporate reputation has a significantly positive impact on the level of strategic CSR. Existing studies mostly focus on examining how CSR initiatives increase reputational capital $[13,29,66]$. This study identifies the role of corporate reputation in fostering a firm's strategic CSR initiatives. Corporate reputation is built over time. It reflects a firm's consistent efforts in fulfilling stakeholders' implicit claims and also reflects its stakeholders' expectations about future implicit claims. To sustain its strong reputation, a firm needs to effectively respond to stakeholder expectations, and thus be more willing to engage in strategic CSR. Third, we find that customer awareness has a significantly positive impact on the level of strategic CSR. Existing studies mostly analyze corporate visibility from the public's perspective and identify corporate visibility as a key factor in affecting a firm's CSR initiatives [26,33,34]. This study analyzes corporate visibility from the customers' perspective. Specifically, a firm with elevated customer awareness draws greater corporate visibility and possesses a higher degree of exposure and attention from external stakeholders. This means that it will be damaged more severely by negative opinions. It is particularly important for such firms to fulfill stakeholders' implicit claims through strategic CSR, thus reinforcing trust from external stakeholders. Apart from this, low customer awareness is considered a key factor 
that accounts for a firm's failure to benefit from its CSR initiatives [68-70]. Several studies show that when customers make purchase decisions, they will take into consideration the CSR activities carried out by firms [91,92]. With elevated customer awareness, a firm will be more likely to inform customers about its CSR initiatives, thus boosting the value of its CSR activities. Thus, a firm with enhanced customer awareness will be more motivated to engage in strategic CSR.

Understanding the role of strategic CSR in responding to external stakeholder claims is important to management in several respects. First, a firm has to understand its stakeholders' implicit claims before developing an effective CSR strategy. Implicit claims reflect promises of quality, service levels, and good work conditions that are not explicitly stated in any contracts [23]. A firm's strategic CSR initiatives should start with identifying its promises to stakeholders. Second, a stronger reputation will reinforce a firm's strategic CSR initiatives, which puts the firm in a better position to achieve social and financial success. Therefore, for firms with a strong reputation, engaging in strategic CSR will be more important to their corporate sustainability than for other firms. Third, with greater customer awareness, a firm is under greater pressure to engage in strategic CSR, making them more likely to build close relationships with their customers through strategic CSR initiatives.

This study has several limitations. First, the research sample consists of publicly-listed firms, which means that our results may not hold for small or medium companies. Given that the business models of small and mid-sized firms are different from those of large firms [93], future research could focus on firms with different sizes to obtain additional information. Second, this study uses firms which have published CSR reports from 2012 to 2014 as research samples and is limited by a lack of access to more recent data. Future research may extend the sample field to conduct a longitudinal analysis and examine if the motivation of a firm's strategic CSR initiatives changes over time. Regarding the direction of future research, this study offers the following suggestions. First, future studies may examine whether a firm experiences different pressures in fulfilling different stakeholders' implicit claims while also looking at how these differences affect a firm's strategic CSR initiatives. Second, future research may identify other factors that affect a firm's corporate visibility, and examine how these factors affect a firm's engagement in strategic CSR. Finally, future studies could examine how industry characteristics affect a firm's motivation to undertake strategic CSR, given that corporate reputation may be more important in some industries than others.

Author Contributions: Conceptualization, S.-H.Y. and W.-C.L.; data curation, W.-C.L.; writing一original draft, S.-H.Y.; writing-review and editing, S.-H.Y. All authors have read and agreed to the published version of the manuscript.

Funding: This research received no external funding.

Conflicts of Interest: The authors declare no conflict of interest.

\section{References}

1. Kuokkanen, H.; Sun, W. Companies, meet ethical consumers: Strategic CSR management to impact consumer choice. J. Bus. Ethics 2019. [CrossRef]

2. Vishwanathan, P.; van Oosterhout, H.J.; Heugens, P.P.M.A.R.; Duran, P.; van Essen, M. Strategic CSR: A concept building meta-analysis. J. Manag. Stud. 2019. [CrossRef]

3. Lii, Y.S.; Lee, M. Doing right leads to doing well: When the type of CSR and reputation interact to affect consumer evaluations of the firm. J. Bus. Ethics 2012, 105, 69-81. [CrossRef]

4. Nelling, E.; Webb, E. Corporate social responsibility and financial performance: The "virtuous circle" revisited. Rev. Quant. Financ. Account. 2009, 32, 197-209. [CrossRef]

5. Arevalo, J.; Aravind, D. Strategic outcomes in voluntary CSR: Reporting economic and reputational benefits in principles-based initiatives. J. Bus. Ethics 2017, 144, 201-217. [CrossRef]

6. Boesso, G.; Favotto, F.; Michelon, G. Stakeholder Prioritization, Strategic Corporate Social Responsibility and Company Performance: Further Evidence. Corp. Soc. Responsib. Environ. Manag. 2015, 22, $424-440$. [CrossRef] 
7. Shiu, Y.M.; Yang, S.L. Does engagement in corporate social responsibility provide strategic insurance-like effects? Strateg. Manag. J. 2017, 38, 455-470. [CrossRef]

8. Chandler, D.; Werther, W.B. Strategic Corporate Social Responsibility: Stakeholders, Globalization, and Sustainable Value Creation, 3rd ed.; Sage Publications: Los Angeles, CA, USA, 2014.

9. Cheng, W.; Appolloni, A.; D'Amato, A.; Zhu, Q. Green public procurement, missing concepts and future trends-A critical review. J. Clean. Prod. 2018, 176, 770-784. [CrossRef]

10. Pistoni, A.; Songini, L.; Perrone, O. The how and why of a firm's approach to CSR and sustainability: A case study of a large European company. J. Manag. Gov. 2016, 20, 655-685. [CrossRef]

11. Setó-Pamies, D.; Papaoikonomou, E. A multi-level perspective for the integration of ethics, corporate social responsibility and sustainability (ECSRS) in management education. J. Bus. Ethics 2016, 136, 523-538. [CrossRef]

12. Amran, A.; Lee, S.P.; Devi, S.S. The influence of governance structure and strategic corporate social responsibility toward sustainability reporting quality. Bus. Strategy Environ. 2014, 23, 217-235. [CrossRef]

13. Orlitzky, M.; Siegel, D.S.; Waldman, D.A. Strategic corporate social responsibility and environmental sustainability. Bus. Soc. 2011, 50, 6-27. [CrossRef]

14. Manasakis, C.; Mitrokostas, E.; Petrakis, E. Strategic Corporate Social Responsibility by a Multinational Firm; DICE Discussion Paper, No. 246; Düsseldorf Institute for Competition Economics (DICE): Düsseldorf, Germany, 2017; ISBN 978-3-86304-245-5.

15. Maas, K.E.H.; Boons, F.A.A. CSR as a strategic activity: Value creation, redistribution and integration. In Innovative CSR: From Risk Management to Value Creation; Louche, C., Idowu, S., Leal Filho, W., Eds.; Greenleaf: London, UK, 2010; pp. 154-172.

16. Marques-Mendes, A.; Santos, M.J. Strategic CSR: An integrative model for analysis. Soc. Responsib. J. 2016, 12, 363-381. [CrossRef]

17. McWilliams, A.; Siegel, D. Creating and capturing value: Strategic corporate social responsibility, resource based theory and sustainable competitive advantage. J. Manag. 2011, 37, 1480-1495. [CrossRef]

18. Acquier, A.; Valiorgue, B.; Daudigeos, T. Sharing the shared value: A transaction cost perspective on strategic CSR policies in global value chains. J. Bus. Ethics 2017, 144, 139-152. [CrossRef]

19. Buysse, K.; Verbeke, A. Proactive environmental strategies: A stakeholder management perspective. Strateg. Manag. J. 2003, 24, 420-430. [CrossRef]

20. Cornell, B.; Shapiro, A.C. Corporate stakeholders and corporate finance. Financ. Manag. 1987, 16, 5-14. [CrossRef]

21. Eesley, C.; Lenox, M.J. Firm responses to secondary stakeholder action. Strateg. Manag. J. 2006, $27,765-781$. [CrossRef]

22. Freeman, R.E. Strategic Management: A Stakeholder Approach; Pitman Publishing: Boston, MA, USA, 1984.

23. devine, I.; Halpern, P. Implicit claims: The role of corporate reputation in value creation. Corp. Reput. Rev. 2001, 4, 42-49. [CrossRef]

24. Fombrun, C.J. Corporate Reputation: Research and Practice; Conversazione: Santa Fe, NM, USA, 2002.

25. Fu, L.; Boehe, D.; Orlitzky, M.; Swanson, D.L. Managing stakeholder pressures: Toward a typology of corporate social performance profiles. Long Range Plan. 2019, 52, 101847. [CrossRef]

26. Li, Z.F.; Morris, T.; Young, B. Corporate visibility in print media and corporate social responsibility. Sustainability 2009, in press.

27. Manning, B.; Braam, G.; Reimsbach, D. Corporate governance and sustainable business conduct-Effects of board monitoring effectiveness and stakeholder engagement on corporate sustainability performance and disclosure choices. Corp. Soc. Responsib. Environ. Manag. 2019, 26, 351-366. [CrossRef]

28. Tourky, M.; Kitchen, P.; Shaalan., A. The role of corporate identity in CSR implementation: An integrative framework. J. Bus. Res. 2019. [CrossRef]

29. Aguilera-Caracuel, J.; Guerrero-Villegas, J. How corporate social responsibility helps MNEs to improve their reputation: The moderating effects of geographical diversification and operating in developing regions. Corp. Soc. Responsib. Environ. Manag. 2018, 25, 355-372. [CrossRef]

30. Arikan, E.; Kantur, D.; Maden, C.; Telci, E.E. Investigating the mediating role of corporate reputation on the relationship between corporate social responsibility and multiple stakeholder outcomes. Qual. Quant. 2016, 50, 129-149. [CrossRef] 
31. Pérez-Cornejo, C.; de Quevedo-Puente, E.; Delgado-García, J.B. How to manage corporate reputation? The effect of enterprise risk management systems and audit committees on corporate reputation. Eur. Manag. J. 2019, 37, 505-515. [CrossRef]

32. Shamma, H.M.; Hassan, S. Customer and non-customer perspectives for examining corporate reputation. J. Prod. Brand Manag. 2009, 18, 326-337. [CrossRef]

33. El Ghoul, S.; Guedhami, O.; Nash, R.; Patel, A. New evidence on the role of the media in corporate social responsibility. J. Bus. Ethics 2019, 154, 1051-1079. [CrossRef]

34. Waris, A.; Alsayegh, M.F.; Ahmad, Z.; Mahmood, Z.; Iqbal, J. The relationship between social visibility and CSR disclosure. Sustainability 2018, 10, 866. [CrossRef]

35. Lantos, G.P. The boundaries of strategic corporate social responsibility. J. Consum. Mark. 2001, 18, 595-632. [CrossRef]

36. Gelbmann, U. Establishing strategic CSR in SMEs: An Australian CSR quality seal to substantiate the strategic CSR performance. Sustain. Dev. 2010, 18, 90-98. [CrossRef]

37. Hillenbrand, C.; Money, K. Corporate responsibility and corporate reputation: Two separate concepts or two sides of the same coin? Corp. Reput. Rev. 2007, 10, 261-277. [CrossRef]

38. Hopkins, M. Why Corporate Social Responsibility? The Planetary Bargain Corporate Social Responsibility Matters; Earth Scan: London, UK, 2003.

39. Freeman, R.E.; McVea, J. A Stakeholder Approach to Strategic Management. In The Blackwell Handbook of Strategic Management; Hitt, M.A., Freeman, R.E., Harrison, J.S., Eds.; Blackwell Publishing Ltd.: Oxford, UK, 2005.

40. Falck, O.; Heblich, S. Corporate social responsibility: Doing well by doing good. Bus. Horiz. 2007, 50, 247-254. [CrossRef]

41. Porter, M.E.; Kramer, M.R. Creating shared value. Harv. Bus. Rev. 2011, 89, 2-17.

42. Rodrigo, P.; Aqueveque, C.; Duran, I.J. Do employees value strategic CSR: A tale of affective organizational commitment and its underlying mechanism. Bus. Ethics Eur. Rev. 2018, 28, 459-475. [CrossRef]

43. Porter, M.E.; Kramer, M.R. Strategy and society: The link between competitive advantage and corporate social responsibility. Harv. Bus. Rev. 2006, 84, 78-92.

44. Charlo, M.J.; Moya, I.; Muñoz, A.M. Sustainable development in Spanish listed companies: A strategic approach. Corp. Soc. Responsib. Environ. Manag. 2017, 24, 222-234. [CrossRef]

45. Brammer, S.J.; Pavelin, S. Corporate reputation and social performance: The importance of fit. J. Manag. Stud. 2006, 43, 435-455. [CrossRef]

46. Michelon, G.; Boesso, G.; Kumar, K. Examining the link between strategic corporate social responsibility and company performance: An analysis of the best corporate citizens. Corp. Soc. Responsib. Environ. Manag. 2013, 20, 81-94. [CrossRef]

47. Roszkowska-Menkes, M.T. Integrating strategic CSR and open innovation. Towards a conceptual framework. Soc. Responsib. J. 2018, 14, 950-966. [CrossRef]

48. Vallaster, C. Managing a company crisis through strategic corporate social responsibility: A practice-based analysis. Corp. Soc. Responsib. Environ. Manag. 2017, 24, 509-523. [CrossRef]

49. Székely, F.; Knirsch, M. Responsible leadership and corporate social responsibility: Metrics for sustainable performance. Eur. Manag. J. 2005, 23, 628-647. [CrossRef]

50. Aqueveque, C.; Rodrigo, P.; Duran, I.J. Be bad but (still) look good: Can controversial industries enhance corporate reputation through CSR initiatives? Bus. Ethics Eur. Rev. 2018, 27, 222-237. [CrossRef]

51. Baron, D. Business and Its Environment, 7th ed.; Prentice Hall: Upper Saddle River, NJ, USA, 2013.

52. Dupire, M.; M'Zali, B. CSR Strategies in response to competitive pressures. J. Bus. Ethics 2018, 148, 603-623. [CrossRef]

53. Flammer, C. Does product market competition foster corporate social responsibility? Evidence from trade liberalization. Strateg. Manag. J. 2015, 36, 1469-1485. [CrossRef]

54. Hart, O.D. The market mechanism as an incentive scheme. Bell J. Econ. 1983, 14, 366-382. [CrossRef]

55. Fernández-Kranz, D.; Santaló, J. When necessity becomes a virtue: The effect of product market competition on corporate social responsibility. J. Econ. Manag. Strategy 2010, 19, 453-487. [CrossRef]

56. Declerck, M.D.; M'Zali, B. Product Market Competition and Corporate Social Responsibility; Working Paper; University Lille Nord de France: Lille, France, 2012. 
57. McWilliams, A.; Siegel, D. Corporate social responsibility: A theory of the firm perspective. Acad. Manag. Rev. 2001, 26, 117-127. [CrossRef]

58. Bhattacharyya, S.S. Exploring the concept of strategic corporate social responsibility for an integrated perspective. Eur. Bus. Rev. 2010, 22, 82-101. [CrossRef]

59. Walker, K. A systematic review of the corporate reputation literature: Definition, measurement, and theory. Corp. Reput. Rev. 2010, 12, 357-387. [CrossRef]

60. Deephouse, D.L. Media reputation as a strategic resource: An integration of mass communication and resource-based theories. J. Manag. 2000, 26, 1091-1112. [CrossRef]

61. Gotsi, M.; Wilson, A. Corporate reputation: Seeking a definition. Corp. Commun. Int. J. 2001, 6, 24-30. [CrossRef]

62. de Quevedo-Puente, E.; de la Fuente-Sabaté, J.; Delgado-García, J. Corporate social performance and corporate reputation: Two interwoven perspectives. Corp. Reput. Rev. 2007, 10, 60-72. [CrossRef]

63. Roberts, P.W.; Dowling, G.R. Corporate reputation and sustained superior financial performance. Strateg. Manag. J. 2002, 23, 1077-1093. [CrossRef]

64. Mann, S.V.; Sicherman, N.W. The agency costs of free cash flow: Acquisition activity and equity issues. J. Bus. 1991, 64, 213-227. [CrossRef]

65. Tucker, L.; Melewar, T.C. Corporate reputation and crisis management: The threat and manageability of anti-corporatism. Corp. Reput. Rev. 2015, 7, 377-387. [CrossRef]

66. Schnietz, K.E.; Epstein, M.J. Exploring the financial value of a reputation for corporate social responsibility during a crisis. Corp. Reput. Rev. 2005, 7, 327-345. [CrossRef]

67. Lai, C.W.; Ahmad, J. Incorporating stakeholder approach in corporate social responsibility (CSR): A case study at multinational corporations (MNCs) in Penang. Soc. Responsib. J. 2010, 6, 593-610.

68. Servaes, H.; Tamayo, A. The impact of corporate social responsibility on firm value: The role of customer awareness. Manag. Sci. 2013, 59, 1045-1061. [CrossRef]

69. Amatulli, C.; De Angelis, M.; Korschun, D.; Romani, S. Consumers' perceptions of luxury brands' CSR initiatives: An investigation of the role of status and conspicuous consumption. J. Clean. Prod. 2018, 194, 277-287. [CrossRef]

70. Nduneseokwu, C.K.; Qu, Y.; Appolloni, A. Factors influencing consumers' intentions to participate in a formal e-waste collection system: A case study of Onitsha, Nigeria. Sustainability 2017, 9, 881. [CrossRef]

71. Becker-Olsen, K.L.; Cudmore, B.A.; Hill, R.P. The impact of perceived corporate social responsibility on consumer behavior. J. Bus. Res. 2006, 59, 46-53. [CrossRef]

72. Harvey, B. Measuring the effects of sponsorships. J. Advert. Res. 2001, 41, 59-65.

73. McWilliams, A.; Siegel, D.S.; Wright, P.M. Corporate social responsibility: Strategic implications. J. Manag. Stud. 2006, 43, 1-18. [CrossRef]

74. Leisinger, K.M. The corporate social responsibility of the pharmaceutical industry: Idealism without illusion and realism without resignation. Bus. Ethics Q. 2005, 15, 577-594. [CrossRef] [PubMed]

75. Tang, Z.; Hull, C.E.; Rothenberg, S. How corporate social responsibility engagement strategy moderates the CSR-financial performance relationship. J. Manag. Stud. 2012, 49, 1274-1303. [CrossRef]

76. Christmann, P. Effects of "best practices" of environmental management on cost advantage: The role of complementary assets. Acad. Manag. J. 2000, 43, 663-680.

77. Basu, K.; Palazzo, G. Corporate social responsibility: A process model of sensemaking. Acad. Manag. Rev. 2008, 33, 122-136. [CrossRef]

78. Sydow, J.; Schreyögg, G.; Koch, J. Organizational path dependence: Opening the black box. Acad. Manag. Rev. 2009, 34, 689-709.

79. Vermeulen, F.; Barkema, H. Pace, rhythm, and scope: Process dependence in building a profitable multinational corporation. Strateg. Manag. J. 2002, 23, 637-653. [CrossRef]

80. Vergne, J.P.; Durand, R. The missing link between the theory and empirics of path dependence: Conceptual clarification, testability issue, and methodological implications. J. Manag. Stud. 2010, 47, 736-759. [CrossRef]

81. Carter, S.M. The interaction of top management group, stakeholder, and situational factors on certain corporate reputation management activities. J. Manag. Stud. 2006, 43, 1145-1176. [CrossRef]

82. Fang, L.H. Investment bank reputation and the price and quality of underwriting services. J. Financ. 2005, 60, 2729-2761. [CrossRef] 
83. Rhee, M.; Haunschild, P.R. The liability of good reputation: A study of product recalls in the U.S. automobile industry. Organ. Sci. 2006, 17, 101-117. [CrossRef]

84. Waddock, S.A.; Graves, S.B. The corporate social performance-financial performance link. Strateg. Manag. J. 1997, 18, 303-319. [CrossRef]

85. Keim, G.D. Managerial behavior and the social responsibilities debate: Goals versus constraints. Acad. Manag. J. 1978, 21, 57-68.

86. Crifo, P.; Escrig-Olmedo, E.; Mottis, N. Corporate governance as a key driver of corporate sustainability in France: The role of board members and investor relations. J. Bus. Ethics 2019, 159, 1127-1146. [CrossRef]

87. Sahasranamam, S.; Arya, B.; Sud, M. Ownership structure and corporate social responsibility in an emerging market. Asia Pac. J. Manag. 2019. [CrossRef]

88. Li, Z.F.; Patel, S.; Ramani, S. The role of mutual funds in corporate social responsibility. J. Bus. Ethics 2019. [CrossRef]

89. Oh, W.Y.; Chang, Y.K.; Martynov, A. The effect of ownership structure on corporate social responsibility: Empirical evidence from Korea. J. Bus. Ethics 2011, 104, 283-297. [CrossRef]

90. Musteen, M.; Datta, D.K.; Kemmerer, B. Corporate reputation: Do board characteristics matter? Br. J. Manag. 2010, 21, 498-510. [CrossRef]

91. Groza, M.D.; Pronschinske, M.R.; Walker, M. Perceived organizational motives and consumer responses to proactive and reactive CSR. J. Bus. Ethics 2011, 102, 639-652. [CrossRef]

92. Sen, S.; Bhattacharya, C.B. Does doing good always lead to doing better? Consumer reactions to corporate social responsibility. J. Mark. Res. 2001, 38, 225-243. [CrossRef]

93. Stoian, C.; Gilman, M. Corporate social responsibility that "pays": A strategic approach to CSR for SMEs. J. Small Bus. Manag. 2017, 55, 5-31. [CrossRef]

(C) 2020 by the authors. Licensee MDPI, Basel, Switzerland. This article is an open access article distributed under the terms and conditions of the Creative Commons Attribution (CC BY) license (http://creativecommons.org/licenses/by/4.0/). 